\title{
FRANÇA JÚNIOR E A COMÉDIA DE COSTUMES
}

\author{
João Roberto Faria*
}

RESUMO: O presente artigo é um exercício de sintese, no qual se procura estudar as comédias de costumes de França Júnior, situando-as no contexto da produção teatral brasileira do século XIX e analisando os seus procedimentos cômicos.

Palavras-chave: comédia de costumes, comicidade, comédia brasileira.

"Meu ponto final é uma lágrima" Com essas palavras, Artur Azevedo, tristíssimo, encerrou a sua crônica de 28 de setembro de 1890 , na qual transmitiu aos leitores do jornal fluminense Correio do Povo a notícia da morte do amigo e companheiro de vida teatral José Joaquim de França Júnior, ocorrida um dia antes em Poços de Caldas, Minas Gerais. Aos 52 anos de idade, desaparecia prematuramente o comediógrafo consagrado pelo extraordinário sucesso de peças como $\mathrm{As}$ doutoras ou Como se fazia um deputado e o cronista admirado por todo o Rio de Janeiro.

Hoje, passados mais de cem anos, França Júnior ocupa um lugar de destaque na história do teatro brasileiro, saudado invariavelmente por nossos especialistas como o escritor que consolidou a comédia de costumes no Brasil, dando continuidade e força à tradição iniciada por Martins Pena. Essa aproximação entre os dois comediógrafos, feita pela primeira vez por Artur Azevedo, não só é correta como fundamental para se perceber a importância e a vitalidade de uma concepção de teatro popular que dominou os palcos brasileiros ao longo de quase todo o século XIX e durante as três primeiras do atual.

França Júnior era acadêmico da Faculdade de Direito do Largo de São Francisco, quando começou a escrever para o teatro. Ele mesmo relembra, numa saborosa crônica de 1882, que ao assistir à representação do drama Onfália, de Quintino Bocaiúva, em julho de 1860 , sentiu-se motivado a fazer algo no mesmo gênero,

(*) Professor da Universidade de São Paulo. 
isto é, uma peça séria, de pretensões moralizadoras, na qual discutiria uma questão de interesse da sociedade. Depois de algumas tentativas, porém, percebeu que sua índole o empurrava para outra direção: o primeiro esforço resultou na pequena comédia Meia hora de cinismo, um exercício despretensioso de quem aproveitava a própria vivência entre estudantes, para expor alguns de seus costumes em ritmo um tanto farsesco. O enredo frouxo, pouco consistente, girando em torno da dívida de um estudante a um agiota, parecia mero pretexto para que a cena reproduzisse as costumeiras gozações, brincadeiras e bebedeiras que deviam ser comuns nas repúblicas estudantis da velha São Paulo. República modelo, aliás, é o título da segunda comédia em um ato que França Júnior escreveu nesse mesmo período, enquanto ainda cursava a Faculdade de Direito. Embora esse texto esteja perdido, é de supor que se trate de uma variação sobre o mesmo tema da comédia anterior. Quer dizer, já no início da carreira o comediógrafo mostrava-se um observador atento dos costumes à sua volta, característica que aprimoraria a cada nova peça escrita.

Meia hora de cinismo e República modelo foram representadas em São Paulo, em 1861. Nessa época, porém, o centro da vida cultural do país estava no Rio de Janeiro, cidade que presenciava, desde 1855, uma estimulante rivalidade entre dois teatros: o São Pedro de Alcântara e o Ginásio Dramático. No primeiro, pontificava o grande ator romântico João Caetano, com um repertório de melodramas, dramas e tragédias neoclássicas bastante adequado ao seu estilo grandiloqüente de interpretação; no segundo, graças ao trabalho do ensaiador Emílio Doux e, posteriormente, dos artistas Furtado Coelho e Joaquim Augusto, os fluminenses puderam conhecer o repertório realista francês - última moda em Paris - e um modo de interpretação sem exageros, baseado no princípio da naturalidade em cena, isto é, da reprodução dos gestos e falas do cotidiano. A representação de peças de autores como Alexandre Dumas Filho, Emile Augier e Théodore Barrière provocou um verdadeiro entusiasmo pelo teatro nos jovens intelectuais brasileiros. $\mathrm{O}$ apoio ao Ginásio Dramático materializou-se nas crônicas de Machado de Assis, Henrique César Muzzio, Souza Ferreira, e nas produções dramáticas de José de Alencar, Quintino Bocaiúva, Joaquim Manuel de Macedo, Pinheiro Guimarães, Aquiles Varejão e de vários outros autores.

É nesse contexto, ou seja, num clima francamente favorável às atividades teatrais, que França Júnior aparece, desejoso de se alinhar com a reforma realista promovida pelo Ginásio. E é exatamente nesse teatro, em fevereiro de 1862, que é representada a sua primeira comédia em três atos, Os tipos da atualidade. Mais ambicioso ao estrear na corte, o escritor procura agora divertir o espectador, mas ao mesmo tempo passar-lhe algumas lições edificantes. Assim, enquanto sustenta a comicidade com o exagero caricato do Barão da Cutia, aborda uma questão de interesse da sociedade, a do casamento por dinheiro, por meio de discussões moralizadoras. 
Essa dicotomia provoca um desequilíbrio na comédia. São visíveis as dificuldades que França Júnior enfrentou ao escrevê-la. Enquanto sua vocação o fazia criar os tipos cômicos do Barão da Cutia, Gasparino e Porfíria, personagens apreendidos pelo ângulo da deformação caricatural e que vivem situações hilariantes, a obrigação de estar na moda e de adequar-se ao repertório típico do Ginásio o levou a criar Carlos, Mariquinhas e D. Ana como reproduções da vida real, daguerreótipos, como se dizia na época.

As diferenças entre os dois grupos de personagens, como não poderia deixar de ser, estende-se à própria ação da comédia. Quando, por exemplo, está em cena o Barão da Cutia, a comicidade ganha o primeiro plano. Desde a entrada, no primeiro ato, até o final, ele é o caipira bronco e desajeitado, completamente inadaptado à vida da corte. Nessa linha, França Júnior explora o mesmo filão de onde nasceu a comédia Um sertanejo na corte, de Martins Pena. Por outro lado, quando Carlos e Mariquinhas contracenam, ou quando o rapaz discute com D. Ana, a peça adquire a naturalidade da comédia realista e incorpora inclusive as tiradas moralizantes - sobretudo contra o casamento por dinheiro - tão comuns no repertório francês e brasileiro do Ginásio.

As qualidades de $O$ s tipos da atualidade restringem-se à caracterização dos personagens e à criação de situações cômicas. No plano do enredo, percebe-se a inexperiência do jovem dramaturgo, incapaz ainda de encontrar as melhores soluções para o conflito instaurado no primeiro ato, entre a intransigência de $\mathrm{D}$. Ana, que deseja casar a filha com o endinheirado Barão da Cutia, e seu antagonista Carlos. Diante do impasse, França Júnior apela para um recurso fácil, exterior à ação da comédia: na passagem do segundo para o terceiro ato, Carlos recebe uma herança de um tio e fica mais rico do que o Barão da Cutia. Logicamente D. Ana o aceita como genro e, para coroar seu apego ao dinheiro, casa-se com Gasparino, supondo que ele herdou uma boa herança de Porfiria. O final feliz, para ela, é na verdade um logro, pois o afetado rapaz só tinha em mente o dinheiro de Carlos, que afinal ficaria em família.

O cinismo do desfecho poderia tirar da peça qualquer alcance moralizador, se nos diálogos finais não ficasse claro que o casamento com Gasparino é na verdade o castigo de $D$. Ana.

Nas peças que escreveu em seguida, França Júnior felizmente desistiu do hibridismo empregado em Os tipos da atualidade. Talvez tenha percebido que as discussões sérias, com intuito edificante, só atrapalhavam sua inclinação pela sátira, pela caricatura e pelo deboche farsesco. Além disso, a partir de 1864, 1865, o tipo de peça representada no Ginásio começava a enjoar o grande público, que queria mais diversão e menos lições morais no teatro. O sucesso da opereta Orfeu no Inferno, de Offenbach, que estreou em fevereiro de 1865 e permaneceu durante todo o ano em cartaz, determinou um novo rumo para os palcos brasileiros na ocasião. Os empresários, sintonizados com o gosto popular, abriram as portas do teatro para as operetas francesas, que aqui foram traduzidas, adaptadas, parodia- 
FARIA, João Roberto. França Júnior e a comédia de costumes. Língua e Literatura, n. 20 , p. 49-55, 1992/1993.

das, e para todo tipo de peça que tivesse o intuito de divertir o espectador. Nos anos que se seguiram, a hegemonia do gênero cômico, em suas formas mais variadas, foi total.

França Júnior, bastante à vontade com a nova situação, escreveu cerca de vinte comédias entre 1864 e 1889 . Infelizmente, algumas delas se perderam, de modo que a edição mais recente de sua obra, feita em 1980 pelo antigo Serviço Nacional de Teatro, reúne nove comédias em um ato e cinco comédias em três ou quatro atos.

As primeiras são evidentemente mais simples, construídas por vezes em torno de uma única idéia ou de um único tipo cômico. Entrei para o clube Jâcome, por exemplo, explora apenas a obsessão de um homem por cavalos. Toda a comicidade está centrada naquilo que Henri Bergson chama de "rigidez" em seu clássico $O$ riso. Ou seja: o personagem age mecanicamente, repetindo um comportamento que vai se mostrando extravagante, exagerado e conseqüentemente cômico. Já $O$ tipo brasileiro ilustra a comédia centrada numa única idéia: satirizar o costume nativo de valorizar somente o que é estrangeiro. Em cena, o inglês espertalhão encanta o brasileiro imbecil com projetos de obras absurdas, vendendo-os como geniais, mas no final é desmascarado por um jovem e inteligente filho da terra.

Se em ambos os casos é possível perceber certas semelhanças com Martins Pena - Entrei para o clube Jâcome repete o procedimento utilizado em $O$ diletante e $O$ tipo brasileiro lembra $O$ inglês maquinista -, a verdade é que todas as comédias curtas de França Júnior, de alguma forma, confirmam tal afinidade. Não que haja cópia de enredos. É indiscutivel a originalidade e a qualidade de comédias como $O$ defeito de familia e Maldita parentela, para citarmos as melhores realizações desse conjunto. Mas, concretamente, os dois comediógrafos lançam mão do mesmo arsenal de recursos do que a poética clássica chamou de "baixo cômico". Em ambos, proliferam os apartes, os estrangeiros e brasileiros broncos estropiando o português, as pancadarias, os disfarces, os esconderijos, as paródias, as coincidências por vezes inverossímeis, os quiproqüós, os tipos enrijecidos, as caricaturas, tudo em função do ritmo cômico que caracteriza a farsa.

França Júnior soube usar com muita competência esses recursos todos. Se nem sempre conseguiu um resultado excepcional - parecem-me inferiores Ingleses na costa, Amor com amor se paga e Dois proveitos em um saco - há que se destacar uma pequena obra-prima entre essas comédias curtas: Maldita parentela. A ação se passa no Rio de Janeiro, em 1871, na casa elegante de Damião Teixeira, que dá uma festa para viscondes, barões e autoridades. Eis que chegam os parentes pobres da esposa, a "maldita parentela" que vem estragar o brilho da festa. É como se um bando de personagens saídos das comédias de Martins Pena tivesse invadido o universo da rica burguesia fluminense. O contraponto propicia um excelente rendimento cômico, trazendo para o primeiro plano os tipos enrijecidos e as situações engraçadas que alimentam o enredo. 

n. 20, p. 49-55, 1992/1993.

As comédias curtas de França Júnior foram importantes para que seu nome se tornasse conhecido no meio teatral. Mas foram as comédias longas que o consagraram. Direito por linhas tortas, encenada em 1870, revela bem a sua capacidade de sustentar a intriga por quatro atos, sem perda de interesse ou ritmo cômico. Com os mesmos recursos das comédias anteriores, mas combinando a comicidade de situações com a descrição de costumes, o autor explora uma idéia muito simples: o que acontece numa casa quando o marido não tem voz e a mulher manda em tudo, exageradamente? Assim é apresentado o casamento de Luís com Inacinha, no segundo ato, inevitavelmente cômico, por força da surpresa que é a transformação da mocinha da roça tão encantadora no primeiro ato em uma megera desbocada e grossa. Isso, por um lado. Porque por outro se confirma uma expectativa sutilmente insinuada na advertência que o amigo Miguel fizera a Luís, lembrando-lhe que antes de se casar devia "estudar" a sogra. Ora, é claro que a filha vai reproduzir o comportamento da mãe, com a agravante de trazê-la para morar em sua casa, na corte.

O segundo ato da comédia é realmente divertido. As duas mulheres não dão sossego aos respectivos maridos, gritam o tempo todo, usam expressões grosseiras, dão ordens, batem nos escravos, fazem o diabo e não cuidam da casa, já que só se preocupam com roupas e passeios. França Júnior trabalha com graça o estereótipo da sogra execrável e a inversão dọs papéis no casamento. E nos dois últimos atos, ao reverter a situação para o que seria a "normalidade" desses papéis - os maridos mandando e as mulheres obedecendo -, instaura uma movimentada comicidade farsesca, que talvez pareça exagerada aos leitores pouco afeitos a esse tipo de peça.

Menos vulneráveis a possíveis restrições nessa linha são as excelentes comédias Como se fazia um deputado e Caiu o ministério, representadas em 1882. Não que dispensem os recursos farsescos. Mas ambas são corrosivas sátiras de costumes políticos que alcançam um efeito cômico mais crítico, em função da abrangência do assunto abordado. Assim, na primeira é todo o sistema eleitoral do Império que surge retratado com as cores da corrupção e da desonestidade. Numa seqüência de cenas hilariantes, o Major Limoeiro lança mão de vários métodos fraudulentos para assegurar a eleição a deputado provincial do sobrinho Henrique, jovem bacharel de Direito. Verdadeiro meneur du jeu da comédia, ele articula também o casamento do rapaz com a filha do seu principal adversário político, estratégia que garante sempre "o governo em casa", esteja no poder o Partido Conservador ou o Partido Liberal. O Major Limoeiro é um pragmático, para quem os fins justificam os meios. Já mudou de partido várias vezes, "por altas conveniências sociais", como diz, acrescentando: “... se o virar casaca fosse crime, as cadeias do Brasil seriam pequenas para conter os inúmeros criminosos que por aí andam" É triste constatar que essas palavras, escritas há mais de cem anos, poderiam estar presentes numa comédia de costumes dos nossos tempos. E há muito mais na sátira demolidora de França Júnior, na qual nem mesmo os 

n. 20 , p. $49-55,1992 / 1993$.

jovens, que geralmente se opõem aos velhos nas farsas de costumes, escapam do olhar severo do autor.

Pôr a política a serviço dos interesses pessoais é também a prática dos personagens de Caiu o ministério. Aqui, as freqüentes crises dos gabinetes ministeriais, que se sucediam no poder com incrivel rapidez, são o ponto de partida da comédia. A fragilidade das instituições facilitava a corrupção e o clientelismo, como se percebe no primeiro ato. A cada anúncio de mudanças no governo e a cada boato sobre os possíveis nomes do novo ministério, o Rio de Janeiro agitava-se com as lutas dos bastidores. França Júnior satiriza a formação dos gabinetes, denunciando que o apadrinhamento valia mais do que a competência, e arma o enredo em torno de um personagem que é designado Presidente do Conselho de Ministros. Como não poderia deixar de ser, sua vida vira um inferno. Não só porque tem que aturar as bajulações, os pedidos de emprego, as brigas políticas, mas sobretudo porque a mulher e a filha o enchem de dividas, argumentando que o cargo de ministro exigia certa pompa, e o fazem defender no Conselho a concessão de privilégio para um inglês "maquinista" explorar uma estapafürdia linha de trens movidos a cachorros. Tudo porque Mr. James seria um bom partido para a mocinha. A ridicularização desse tipo de política é arrasadora.

A última comédia importante de França Júnior, e sua melhor realização no gênero, intitula-se As doutoras. Representada em 1889, essa comédia apresentava ao público fluminense da época uma inquietação que devia estar no ar ou pelo menos na cabeça de muita gente: qual o futuro da família numa sociedade em que as mulheres começavam a freqüentar as faculdades e a trabalhar como profissionais liberais, no mesmo nível dos homens?

Há informações de que a primeira médica brasileira formou-se na Bahia, em 1887. E é bem provável que nessa altura outras moças estivessem no mesmo caminho. Quer dizer, França Júnior trabalhou um tema atualíssimo, pondo em cena, para exacerbar os conflitos, um médico e uma médica recém-formados, que se casam. Como não defendem as mesmas teorias, as discussões científicas entre ambos são freqüentes e inevitavelmente cômicas, sobretudo quando acompanhadas e comentadas pela mãe da moça por uma criada tagarela. $\mathrm{O}$ deslocamento dos termos médicos e seu uso exagerado funcionam tão bem quanto a retórica inflamada da outra doutora da comédia, uma advogada que fala sempre como se estivesse no fórum.

A comicidade de palavras e situações domina os três primeiros atos. No plano do enredo, é claro que as discussões científicas transformam-se em rivalidade profissional e brigas que culminam num processo de separação. Mas tudo entra nos eixos com uma providencial gravidez da personagem e uma violenta comoção que a faz desistir da medicina. No quarto ato, completamente feliz, ela se contenta em ser esposa e mãe. Simetricamente, o mesmo acontece com a advogada falante.

$\mathrm{O}$ desfecho da peça revela obviamente um comediógrafo conservador, que hoje irritaria as feministas. Mas do ponto de vista estritamente teatral, o desfecho 
tem um rendimento cômico extraordinário. A inversão das situações iniciais gera um contraponto forçosamente engraçado, ratificando a ridicularização das "femmes savantes" que haviam sido caracterizadas pela já mencionada rigidez de Henri Bergson. Com essa peça, que desfrutou de enorme prestígio junto ao público, França Júnior coroou com brilho a sua obra teatral, seguramente uma das mais importantes do repertório brasileiro.

\section{BIBLIOGRAFIA}

BERGSON, Henri. O riso. Trad. de Nathanael C. Caixeiro. Rio de Janeiro, Zahar, 1980. FRANÇA JÚNIOR, J. J. de. Teatro de França Jünior. Rio de Janeiro, Funarte/ Serviço Nacional de Teatro, 1980, $2 \mathrm{v}$.

MAGALDI, Sábato. Panorama do teatro brasileiro. São Paulo, Difel, 1962.

MAGALHÃES JR., R. Artur Azevedo e sua época. 4 ed. São Paulo, Lisa, 1971.

PÁDUA, Antônio de. Aspectos do estilo cômico em França Júnior. In: DIVERSOS. Coletânea. Rio de Janeiro, MEC, 1963, p.11-32.

PRADO, Décio de Almeida. A evolução da literatura dramática. In: COUTINHO, Afrânio (org.). A literatura no Brasil. 2 ed. Rio de Janeiro, Sul Americana, 1971, vol.6, p.7-37.

SOUSA, Galante de. O teatro no Brasil. Rio de Janeiro, MEC/INL, 1960, 2 v.

VOLTZ, Pierre. La comédie. Paris, Armand Colin, 1964.

ABSTRACT: This article presents a synthetical approach to the comedies of manners by França Júnior. This approach localizes the plays in the context of the Brazilian theatrical production during the 19th century and analyzes the mechanisms by wich their comic effect is achieved.

Key-Words: comedy of manners, comicness, Brazilian comedy. 